\title{
FORESTRY
}

\section{Neolamarkia cadamba - A Potential Tree Species for Domestication through Agroforestry System}

\section{S. Saravanan}

Tropical Forest Research Institute, RFRC (PO), Mandla Road, Jabalpur - 482021. Madhya Pradesh, India

Corresponding author: ifgtbsara9@gmail.com (ORCID ID: 0000-0003-3203-2878)

Paper No. 807

Received: 03-07-2019

Revised: $10-10-2019$

Accepted: 20-11-2019

\begin{abstract}
Agroforestry is the management and integration of trees, crops and/or livestock on the same plot of land and can be an integral component of productive agriculture for higher economic returns. With the ever increasing population during past decades, the land resources for cultivation are shrinking. This situation calls for the adoption of 'Agroforestry systems' which is not only an efficient land management but also has promising role in maintaining environmental balance. In India, farmers' are lacking in information on choosing the combination or compatibility of agricultural crops and tree species for different agroforestry systems under various agro-ecological zones. The benefits of successful agroforestry systems have an economic, environmental and social dimension. It is important to bring out a technology package on successful and viable agroforestry systems suitable for different agro-ecological zones for socioeconomic upliftment of rural farming community. The fast growing, multipurpose and indigenous trees, which could combine very well with annual crops and provide maximum economic returns in the short period of time is preferred under agroforestry systems. Neolamarkia cadamba is one such tree having fast growth in nature and highly suitable for agroforestry systems for higher economic returns. N. cadamba is a species having various end uses for pulp, ply and most preferred for pencil making. Though many phyto-chemicals and pharmacological compounds have been identified from this tree species, the species has not been domesticated so far under agroforestry systems. A detailed review on the status of this species including nursery techniques, agroforestry system establishment, etc. is presented in this paper.
\end{abstract}
Highlights
(0 This article will give an overall idea and importance of 'Kadam'.
0 An evergreen, tropical fast growing tree highly suitable for pencil making and for pulp.
0 Need domestication under agroforestry.

Keywords: Neolamarkia cadamba, Agroforestry systems, Agro ecological-zones, Growth parameters

Cultivating trees in combination with agricultural crops in various combinations is an ancient practice throughout the world. Agroforestry is the management and integration of trees, crops and/or livestock on the same piece of land and can be an integral component of productive agriculture. Adoption of agroforestry systems, which is not only an efficient land management system but also has promising role in maintaining environmental balance. However, there were many gaps, particularly, more scientific approach to intercropping and research on tree-crop interactions is need to be addressed and it was suggested that greater efforts were required to be put in with respect to sustained yield of agricultural crops (Nair 1979). Agroforestry is found to be the most desirable strategy for maintaining social, economic and ecological sustainability in India. Agroforestry has the potential to achieve sustainability in agriculture while optimizing its productivity and mitigating climate change impact. Agroforestry has significant potential to provide employment to rural and urban population through production, industrial application and value addition ventures. 
It is also recognized that agroforestry is perhaps the only alternative to meeting the target of increasing forest or tree cover to $33 \%$ from the present level of less than 25\%, as envisaged in the National Forest Policy 1988). Current estimates show that about $65 \%$ of the country's timber requirement is met from the trees grown on farms. Agroforestry also generates significant employment opportunities. Different kinds of agroforestry practices have been recognized in India (Puri and Nair 2004) and Poplar is one among the fast growing exotics widely adopted by farmers in agrisilvicultural system in north India (Bhardwaj and Gupta 1993).

Tree based land use practices could accompany both tangible and intangible benefits, especially in farm lands. In India, about $20-25 \%$ of the land in nearly all the states is degraded, either barren or cultivable wastes or fallow. Moreover, due to the implementation of various schemes to promote tree farming, the awareness on tree cultivation in farmlands has increased and this is mainly to increase the small timber production, fuel, fodder, etc. for self sustenance. Because of the climatic vagaries, farmers also slowly shifting their nature of cultivation with mixture of tree components to compensate the agricultural losses through tree components especially under dry land agroforestry systems.

In India, farmers are lacking in information on choosing the combination or compatibility of agricultural crops and tree species for different agroforestry systems under various agro-climatic zones. The benefits of successful agroforestry models have an economic, environmental and social dimension. It is important to bring out a technology package on successful viable agroforestry systems suitable for various agro-ecological zones of India for socioeconomic upliftment of rural farming community. The present study reveals that, establishment of $N$. cadamba based agroforestry systems in different agro-ecological zones will provide additional income to farmers in a short rotation period.

\section{Taxonomy}

N. cadamba Roxb (synonym: Anthocephalus cadamba and Anthocephalus indicus) commonly known as burflower-tree, Laran, and Leichhardt pine and called 'kadam' and Amboina is a large, ornamental tree with a broad, umbrella-shaped crown belongs to Rubiaceae family has the chromosome number of 22 (Fox 1971). The vernacular names are Kadam Kadamb (Hindi), Vellaikadambu (Tamil), Katampu (Malayalam), Kaduavalatige (Kannada) and Rudrakskamba (Telugu).

\section{Distribution and Environmental Requirements}

N. cadamba occurs naturally from Sri Lanka, India, Nepal and Bangladesh eastward through Malaysia to New Guinea. It has been planted as an ornamental and plantation tree and has been successfully introduced in South Africa, Puerto Rico, Surinam, Taiwan and other tropical and subtropical countries. Kadam is a typical pioneer and is very common in secondary forest. Sometimes large individuals can be found in primary rain forests. It is found scattered in semi evergreen to evergreen forests throughout the greater part of India except in arid regions of Rajasthan (Champion and Seth (1968). The most important condition for growth is light. Kadam does not tolerate shade. In its natural habitat, maximum temperature varies from 32$43^{\circ} \mathrm{C}$ in the shade and minimum temperature from $3-15.5^{\circ} \mathrm{C}$. Kadam is sensitive to frost. The average annual rainfall ranges from $1500-5000 \mathrm{~mm}$ or more. Kadam may, however, also occur locally on much drier sites with as little as $200 \mathrm{~mm}$ annual rainfall (e.g. in parts of central South Sulawesi). Near the equator it is found from sea-level up to $1000 \mathrm{~m}$ altitude. It grows on a variety of soils but is more abundant and dominant on well-aerated fertile soils. Kadam does not grow well on leached soils, even when their physical conditions are good. It occurs on river banks and in the transitional zone between swampy, permanently flooded areas and the drier loams, in areas which are periodically flooded (Pollard 1969).

\section{Description}

Kadam is a medium-sized to large deciduous trees up to $45 \mathrm{~m}$ tall. The bole is straight and cylindrical, often branchless for more than $25 \mathrm{~m}$, up to $100(-160)$ $\mathrm{cm}$ in diameter but generally less, sometimes with small buttresses up to $2 \mathrm{~m}$ high and extending up to $60 \mathrm{~cm}$ from the trunk (Luna 1996). The outer bark very light and smooth when young, grey to grey-brown with shallow fissures when old, sometimes with small ridges, often cracked and 
rather coarsely flaky; crown typically umbrellashaped, small; branches horizontally spreading and drooping at the tip, arranged in tiers, scars of fallen branches visible for several years on young stems. Leaves opposite, simple, more or less sessile to petiolate, ovate to elliptical, $15-50 \mathrm{~cm} \times 8-25 \mathrm{~cm}$, in young fertilized trees sometimes much larger, subcordate at base, acuminate at apex; stipules interpetiolar, narrowly triangular, deciduous. Inflorescence consisting of terminal, solitary, globose heads without bracteoles. Flowers subsessile on a glabrous receptacle, bisexual, actinomorphic, 5-merous; calyx tube funnel-shaped, with narrow lobes pubescent outside; corolla gamopetalous, saucer-shaped with a narrow tube, the narrow lobes imbricate in bud; stamens 5 , inserted on the corolla tube, filaments short, anthers basifixed; ovary inferior, 2-locular, sometimes 4-locular in the upper part, style exserted, stigma spindle-shaped. Fruitlets numerous, somewhat fleshy, the upper part containing 4 hollow or solid structures. Seed somewhat trigonal or irregular-shaped, not winged. Seedling with epigeal germination; cotyledons sessile, herbaceous, acute, green; leaves opposite (Troup 1921).

\section{Silviculture and Management}

Natural regeneration from seed can be effected by clearing the soil at the time of seed ripening during abundant seed production season. Natural regeneration of the species is sparse due to its minute seeds shed during the hot summer are often carried to a distance by the wind. The seeds are produced in vast numbers, but the proportion of seedlings which survive and establish themselves is relatively very small. There is much difference in performance between trees from different seed sources as well as between plantations with a different topography. Notable differences in performace related to site conditions have been observed, even within a single plantation. The rotation period depends upon soil characteristics. In the Philippines, economic rotations applied in plantations were 5 years for pulp wood and 7 years for the combination of pulp wood and sawn timber. For match wood production, 4-year rotation is followed in kadam.

\section{Seed Collection and Processing}

The ripened fruits are orange in colour, harvested from the trees during the months of September to December by climbing or shaking the branches after spreading covers on the ground. The best time to collect seed is middle to latter part of August. The collected fruits can be allowed to rot for three to four days and pulp is washed off by hands in a bucket of water, seeds settled at the bottom are taken out and dried well. The fruits are rubbed to form a paste like slurry, which is passed through a $0.50 \mathrm{~mm}$ sieve plate and shaken vigorously.

The blackish paste sieved through the plate is collected into a pan and dried to extract seeds. Average dry weight of each fruit is $11.5 \mathrm{gm}$ and wet weight $50 \mathrm{gm}$. Each fruit on an average yields 456 mg of pure seeds. Other method is by cutting the fruits into small parts and allowing them to dry and after a few days crush the small parts and separate the seeds. One gram has around 23,000-25,000 seeds. The separated seeds are allowed to dry in shade and can be stored in air tight container for 9 months (.

In the indigenous method, the dried fruits are rubbed against the rough surface of a simple device until only the receptacle remains. The device consists of a tin sheet on one side of which holes of about $0.4 \mathrm{~cm}$ dia are made with a nail so that uneven projections appear on the reverse side which be used for rubbing surface. After rubbing, the disintegrated fruit parts are collected and passed through a fine sieve (hole size about $0.5 \mathrm{~mm}$ ). The sieved seeds are winnowed and 95\% seed purity can be obtained. About $6 \mathrm{~kg}$ of dry fruits yield 1 $\mathrm{kg}$ of seed. Good germination is obtained by this method which shows that seeds do not get damaged by rubbing. No of seeds per $\mathrm{kg}$ and plants per $\mathrm{kg}$ in West Bengal are 9, 20,000 and 5,500 respectively (Venator 1972).

\section{Nursery Establishment}

The sieved seeds need no pre-sowing treatment. Seeds of about $0.1 \mathrm{~g}$ (about 2500 seeds) can be sown in galvanized or wooden trays filled with fine river sand and soil and treated with fungicide. The seeds are better mixed with sterilized sand before sowing. They are sown in February at the rate of about 0.2 gm of seed per $\mathrm{m}^{2}$ of bed. Winter sowing is not successful. Percentage of germination is high. The germination of Kadam seeds in open beds is generally difficult. Therefore, plants are invariably raised in shaded beds to exclude insolation and 
splashing effects of rain water. Before sowing, the beds are thoroughly wetted and seeds are broadcast on the top taking care that seeds do not get buried in the soil, instead they are patted with hand. After sowing, watering is done with a fine rose can, frequently and sparingly, according to requirements as the young seedling are sensitive to both drought and excessive moisture. Germination takes place in about three weeks from the date of sowing. After germination shading is removed. The germination percentage is $60-90 \%$. The seedlings from the tray can be pricked and transplanted in the poly bag container with fungicide after attaining a height of $5 \mathrm{~cm}$. Shade cover is needed after transplanting. Growth is fast under tropical conditions and plants could reach plantable size $(30 \mathrm{~cm})$ in four to five months. Seedlings require periodic watering in the first stages of development. Common mistakes in propagation are over-watering and associated disease problems, over-shading and allowing the germinants to become too large for easy transplanting leading to malformed tap roots or root curling in the pots. About 2 lakhs seedlings can be obtained from $1 \mathrm{~kg}$ of seeds in nurseries. Out planting is done with $35-50 \mathrm{~cm}$ high seedlings.

\section{Plantation Establishment and Growth}

Kadam grows well in deep moist alluvial soils, often along river banks. The soil should be well drained and should not get affected by flood. The Kadam trees are planted at an espacement of 5 $\times 5 \mathrm{~m}$ spacing during the monsoon season. To ensure successful establishment, seedlings should be planted with their balls of earth. Closer spacing leads to height growth which is not preferred much by pencil and ply wood industry. Wider spacing can be adopted to have more girth and also for intercropping during the initial period (1-2 years).

\section{Agroforestry practices}

It has no adverse effects on the crops sown as under storey if proper care is taken. For better results, the spacing adopted should be at least $5 \times 5 \mathrm{~m}$ or $6 \times$ $6 \mathrm{~m}$. Dry paddy can be cultivated up to 3 years without much difficulty. Once the trees are grown up, it is desirable to change the cropping pattern, i.e., ginger, turmeric etc besides vegetables, pine apple, arhar and pulses. Trees are also planted in the boundaries of the field. Hence in farm forestry, the farmers can get more yields of crops and generate revenue from Kadam tree as well (Singh and Lal 1982). Based on the study carried out in fast growing tree species in different agroecological zones, Kadam registered higher growth and economic returns under agroforestry models due to its fast growth in nature, computability with annual crops, higher economic returns, from wood as well as from intercropping activities, and the Kadam end uses like raw material for paper and pulp and ply. Farmers' can sell their Kadam material for paper and pulp under short rotation period of 3-5 years and sell their material for ply in the rotation period of 8-10 years (Soerianegara and Lemmens 1993; Arvind Bijalwan et al. 2014).

\section{Yield}

In Tamil Nadu, about 70-100 $\mathrm{t} \mathrm{ha}^{-1}$ at a rotation of 6-7 years was realized through seed raised plantations and it can be increased $10-15 \%$ more by introduction of clones and through site-clone matching in six years rotation depending on the fertility level of the soil. Approximate yield calculated by felling the trees in the plantation raised through seeds is as follows:

\begin{tabular}{llllll}
\hline & $\begin{array}{l}\text { Year } \\
\text { (rotation) }\end{array}$ & $\begin{array}{l}\text { Number } \\
\text { of trees }\end{array}$ & $\begin{array}{l}\text { Wood yield } \\
(\mathbf{i n} \mathbf{t})\end{array}$ & $\begin{array}{l}\text { Price } \\
\left.\mathbf{( t}^{-1}\right)\end{array}$ & $\begin{array}{l}\text { Income } \\
(\text { in ₹) }\end{array}$ \\
\hline Tree & 8 & 500 & $\begin{array}{l}122(500 \times \\
\times 225 \mathrm{~kg} \mathrm{tree}^{-1}\end{array}$ & 7000 & 784000 \\
& & & \\
\hline
\end{tabular}

Approximate yield and income ha-1 under irrigated condition. Total net benefit is ₹ 784000/- (@ annual rate of income ₹ 81,994 $\mathrm{yr}^{-1}$ ) (Vijayaraghavan 2014).

In a 20-year rotation, the stand attained an average height of $38 \mathrm{~m}$ and average diameter of $65 \mathrm{~cm}$, producing $350 \mathrm{~m}^{3} \mathrm{ha}^{-1}$ in the final cut. Total production including thinnings amounted to 23 $\mathrm{m}^{3} \mathrm{ha}^{-1} \mathrm{yr}^{-1}$ (Singh 2003 and Krisnawati et al. 2010). Those data refer to all wood, including branches with a diameter of $7 \mathrm{~cm}$ and more. A tree of 50 $\mathrm{cm}$ diameter yields $2.5-3 \mathrm{~m}^{3}$ wood under well management condition.

\section{Wood Properties and Uses}

\section{Properties}

Kadam is a lightweight hardwood. The heartwood is white with a yellow tinge darkening to creamy yellow on exposure, and not clearly differentiated 
from the sapwood ((Martawijaya et al. 1989). The density is $290-465(-560) \mathrm{kg} \mathrm{m}^{3}$ at $15 \%$ moisture content. The grain of the wood is generally straight, texture fine and even. At $15 \%$ moisture content, the wood of kadam has the following mechanical properties: modulus of rupture $50-73 \mathrm{~N} / \mathrm{mm}^{2}$, modulus of elasticity (5000-)6700-9300 N/mm², compression parallel to grain (23-)28-44 N/mm², shear $5-8 \mathrm{~N} / \mathrm{mm}^{2}$, cleavage c. $35 \mathrm{~N} / \mathrm{mm}$ radial and $54 \mathrm{~N} / \mathrm{mm}$ tangential, Janka side hardness 1950-2625 $\mathrm{N}$ and Janka end hardness $3000-4000 \mathrm{~N}$. Kadam is easy to work with hand and machine tools, it cuts cleanly and gives a very good surface, although tearing out may give slight problems. Test results of the machining properties indicate that the wood can be shaped, mortised and sanded with good results, and planed, bored and turned with moderate results. The nailing properties are excellent, and the wood glues well. It peels readily at a cutting angle of $92^{\circ}$, producing good veneer $1.5 \mathrm{~mm}$ thick. It produces sulphate pulp with sufficient papermaking quality. Kraft pulping gives a yield of $48.5 \%$ and pulp of satisfactory brightness and performance as a handsheet. The wood of Kadam contains $47-52 \%$ cellulose, $25.5 \%$ lignin, $16-24 \%$ pentosan, $0.8-1.9 \%$ ash, and very little or no silica. The solubility is $4.7 \%$ in alcohol-benzene, $1.6 \%$ in cold water, $3.1 \%$ in hot water and $18.4 \%$ in a $1 \% \mathrm{NaOH}$ solution. The energy value of the wood is $19800 \mathrm{~kJ} / \mathrm{kg}$. The charcoal is odourless and does not smoke or spark, but the low yield in comparison with other species makes it uneconomic.

\section{Uses}

The wood is extensively used for ceiling boards, light construction work, packing cases, planking, carving and turnery. The wood makes good veneers and plywood suitable for the manufacture of commercial grade plywood and tea chest plywood. In Assam wood is mainly used in the plywood industries. It is also suitable for the manufacture of pencils, match boxes, and splints. Suitable for writing and printing paper giving $48.6 \%$ yield and over $6000 \mathrm{~m}$ breaking length. Brown wrapping paper can also be prepared by sulphate process. Fruits are edible. Bark used for relieving fever and extract of leaves are used for mouth gargle (Kapil et al. 1995).

\section{CONCLUSION}

Kadam is planted in many places in the tropics, production data are scarce. Most of the wood is used locally. Export data on the wood are mixed with data from other, not well-defined lightweight woods. Kadam is becoming one of the most frequently planted trees in the tropics. The preservation of the genetic diversity of kadam seems guaranteed, as the trees are widespread and common, and are planted on a fairly large scale. In India, alone, several hundred thousand ha are estimated to be planted with Kadam and in the future, kadam might compete with the African woods. Because of its very fast growth, its ability to grow on a variety of soils, the absence of serious diseases and pests, and its favourable silvicultural characteristics, kadam is expected to become increasingly important in the near future, when supplies for plywood from natural forests are expected to decrease. The selection of and/or breeding a less site-sensitive provenance should receive priority.

\section{REFERENCES}

Arvind Bijalwan, Manmohan, J.R., Dobriyal and Bhartiya, J.K. 2014.) A potential fast growing tree for Agroforestry and Carbon Sequestration in India: Anthocephalus cadamba (Roxb.) Miq. American Journal of Agriculture and Forestry, 2(6): 296-301.

Bhardwaj, B.B. and Gupta, S.R. 1993. Organic matter dynamics in a Populus deltodies agroforestry system. Int. J. Ecol. Env. Sci., 19: 187-195.

Champion, H.G. and Seth, S.K. 1968. A Revised Survey of Forest Types of India, Govt. of India Press, New Delhi, pp. 404.

Fox, J.E.D. 1971. Anthocephalus chinensis, the laram tree of Sabah. Economic Botany, 25: 221-233.

Kapil, A., Koul, I. and Suri, O.P. 1995. Antihepatotoxic effects of chlorogenic acid from Anthocephalus cadamba. Phytotherapy Research, 9(3): 189-193.

Krisnawati, H., Kallio, M. and Kanninen, M. 2011. Anthocephalus cadamba Miq.: ecology, silviculture and productivity. CIFOR, Bogor, Indonesia.

Luna, R.K. 1996. Plantation trees, IBD Publisher, Dehradun, India.

Martawijaya, A., Kartasujana, I., Mandang, Y.I., Prawira, S.A. and Kadir, K. 1989. Atlas kayu Indonesia Jilid II. Pusat Penelitian dan Pengembangan Hasil Hutan, Bogor, Indonesia

Nair, P.K.R. 1979. Intensive multiple cropping with coconuts in India. Verlag Paul Parey, Berlin/Hamburg, Germany.

Pollard, J.F. 1969. A note on the nursery treatment of two species of Sabah. Malay Forester 32(3): 269-271 
Puri, S. and Nair, P.K.R. 2004. Agroforestry research for development in India: 25 years of experience of a national programme. Agroforestry Systems, 61(1-3): 437-452.

Singh, T.P. 2003. Potential of Farm Forestry in Carbon Sequestration. Indian Forester, 129: 839-843.

Singh, S.P. and Lal, P. 1982. Effect of different spacing treatments on yield from Anthocephalus chinensis plantations. Indian Forester, 108(12): 734-740.

Soerianegara, I. and Lemmens, R.H.M.J. 1993. Plant resources of South-east Asia, 5(1): Timber trees: Major commercial timbers. Pudoc Scientific Publishers, Wageningen, Netherlands.
Troup, R.S. 1921. The Silviculture of Indian Trees. Volume II. International Book Distributors, Dehra Dun, pp. 616-621.

Venator, C.R. 1972. Extraction and germination of Cadamb seed. Research Note. No. ITF14. Institute of Tropical Forestry, Puerto Rico.

Vijayaraghavan, A. 2014. Cultivation Techniques for Neolamarckia cadamba. In: Transfer of Tree Cultivation Technologies to Krishi Vigyan Kendras (KVKs) of Tamil Nadu and Puducherry. Institute of Forest Genetics and Tree Breeding, Coimbatore, India, pp. 28-32. 